\title{
Effects of Fructose-Induced Metabolic Syndrome on Kidney Histology in Rats
}

\author{
Özay GÜLEŞ1*, Musa TATAR² \\ ${ }^{1}$ Afyon Kocatepe University, Faculty of Veterinary Medicine, Department of Histology and Embryology, 03200, Afyon, Turkey \\ ${ }^{2}$ Burdur Mebmet Akif Ersoy University, Faculty of Veterinary Medicine, Department of Histology and Embryology, 15030, \\ Burdur, Turkey
}

\begin{abstract}
Metabolic syndrome is a fatal endocrinopathy, which is progressed towards pandemic, and characterized by insulin resistance, abdominal obesity, dyslipidemia, diabetes mellitus, hypertension and coronary artery disease (CAD). In the present study, it is aimed to investigate the histomorphological and histochemical changes caused by the metabolic syndrome in rat kidneys. For this purpose, the material was divided into two groups: 10 rats in the control group and 15 rats in the experimental group. During 16 weeks, while tap water was given to control group rats, water including 20\% fructose solution was given to experimental group rats as drinking water. At the end of the study, Crossman's triple staining method was performed to determine the histological appearance and histomorphological changes in the sections taken from the kidneys. Periodic Acid Schiff Reagent (PAS) staining method was performed for histochemical analysis. The results of the study showed that the tubulus proximalis diameter, tubulus proximalis glycogen density, and glomerular mesangial matrix density increased, corpusculum renis diameter, width of cavum glomeruli and ascending limb of Henle's loop diameter decreased. In conclusion, it is demonstrated that metabolic syndrome may adversely affect kidney histology and cause renal damage.
\end{abstract}

Keywords: Metabolic syndrome, fructose, histology, kidney, rat

\section{Ratlarda Fruktoz ile Oluşturulmuş Metabolik Sendromun Böbrek Histolojisi Üzerine Etkileri}

\section{ÖZ}

Metabolik sendrom pandemiye doğru ilerleyen, insülin direnci, abdominal obezite, dislipidemi, diabetes mellitus, hipertansiyon ve koroner arter hastalığ1 $(\mathrm{KAH})$ ile karakterize ölümcül bir endokrinopatidir. Sunulan çalışamada metabolik sendromun rat böbreklerinde oluşturduğu histomorfolojik ve histokimyasal değişimlerin araştırılması amaçlanmıştır. Bu amaçla materyal kontrol grubunda 10, metabolik sendrom grubunda 15 rat içerecek şekilde iki gruba ayrild. Kontrol grubundaki ratlara 16 hafta süresince çeşme suyu verilirken, metabolik sendrom grubundaki ratlara içme suyu olarak \% 20 fruktoz çözeltisi verildi. Deneme sürecinin sonunda böbreklerden alınan kesitlerde histolojik görünümü ve histomorfolojik değişimleri belirlemek amaciyla Crossman's üçlü boyama metodu, histokimyasal analiz amaciyla Periyodik Asit Schiff Reagent (PAS) boyama metodu uyguland.. Elde edilen veriler tubulus proksimalis çapı ve glikojen yoğunluğu ile glomerular mezangial matriks yoğunluğunun arttığını, korpuskulum renis çap1, Bowman aralığı genişliği ve çıkan henle çapının azaldığını göstermiştir. Sonuç olarak, metabolik sendromun böbrek histolojisini olumsuz yönde etkileyerek renal hasara sebep olabileceği ortaya konmuştur.

Anahtar Kelimeler: Metabolik sendrom, fruktoz, histoloji, böbrek, rat

To cite this article: Güleș Ö. Tatar M. Effects of Fructose-Induced Metabolic Syndrome on Kidney Histology in Rats. Kocatepe Vet J. (2020) 13(2):203-209 


\section{INTRODUCTION}

Metabolic syndrome is a fatal endocrinopathy characterized by a combination of cardiometabolic risk factors such as insulin resistance, abdominal obesity, atherogenic dyslipidemia, glucose intolerance/diabetes mellitus, high blood pressure and coronary artery disease (CAD) (Zimmet et al. 2005). Metabolic syndrome is also defined by different terms such as insulin resistance syndrome, syndrome $\mathrm{X}$, polymetabolic syndrome, fatal quart, and civilization syndrome. World Health Organization (WHO) emphasized and suggested that it is more appropriate to term all of the risk factors as "metabolic syndrome" in 1998 (Alberti and Zimmet 1998). Metabolic syndrome is an important cause of morbidity that affects more and more people in both developed and developing countries. In addition to environmental factors such as adopting a sedentary lifestyle and changes in nutritional habits, some of the inheritance features play a role in this growth that progresses to pandemic (Ișildak et al. 2004). Insulin resistance is caused by increased blood sugar, excessive secretion of insulin, increased low-density lipoprotein (VLDL cholesterol, bad cholesterol) and increased free fatty acids in the blood (Aganović and Dušek 2007). In particular, the consumption of large amounts of fructose plays a major role in the formation of insulin resistance ( $\mathrm{Ng}$ et al. 2018).

Fructose is a six-carbon monasaccharide found in many foods. It is very easily soluble in water and has a white solid appearance. Many foods such as fruits, honey, roots of some vegetables contain significant amounts of fructose in nature. It is estimated that approximately 240000 tons of fructose is produced naturally every year in the world through autotrophic organisms (Wach 2004). Pure fructose, taken with foods, is not digested. However, when taken as sucrose, the sucrase enzyme in the small intestine catalyzes this disaccharide and decomposes it into its basic units: fructose and glucose. Fructose joins the small intestine without undergoing any change and joins the bloodstream (Ribby et al. 1993). Glucose transporter 5 (GLUT-5) mediates the uptake of fructose into the cell in the small intestine. However, fructose can not be taken into the cell since GLUT-5 is not present in the $\beta$ cells of the brain and pancreas. Therefore, while feeding on a diet rich in fructose, a feeling of satiety does not occur. Since there is no saturation feeling, metabolic syndrome develops due to more food intake (Bray et al. 2004).

To form metabolic syndrome models in laboratory animals, it is given diets including fructose $60-70 \%$ of the total energy or added $10-20 \%$ of fructose to water (Sanchez-Lozada et al. 2007, Gelmez et al. 2013 ). The metabolic syndrome formed by this method in rats increases serum urea, creatinine, aspartate aminotransferase (AST), alanine aminotransferase
(ALT) and glucose levels while decreasing highdensity lipoprotein (HDL, good cholesterol) (Yildırım 2017). Histologically, in the kidneys, it increases the tubulus proximalis area (Oudot et al. 2013, Yang et al. 2014) and width of cavum glomeruli (Yanti et al. 2014), while the corpusculum renis and glomerulus area (Saleh et al. 2017) and the glomerulus diameter are reduced (Yanti et al. 2014). It also causes tubular basement membrane thickness (Öztürk et al. 2005), dilatation of tubules in the medulla area (Kizhner and Werman 2002), glomerular mesangial matrix increase (Kizhner and Werman 2002, Öztürk et al. 2005), mesangial collagen accumulation and Bowman capsule thickness (Kizhner and Werman 2002). Also, it causes tubular degeneration (Yang et al. 2014, Yildırım. 2017), tubular vacuolations (Yildirım, 2017), cortical tubular necrosis (Kizhner and Werman 2002), interstitial inflammation (Kizhner and Werman 2002, De Castro et al. 2013, Yildırım 2017), fat cells accumulation, hemosiderin pigment formation in tubular cell cytoplasmes and glomerulosclerosis formation (De Castro et al. 2013).

In the present study, it is aimed to investigate the histomorphological and histochemical changes caused by the metabolic syndrome in rat kidneys.

\section{MATERIAL and METHODS}

The study was performed with prior permission (no. 64583101/2016/75) from the Ethics Committee of Aydin Adnan Menderes University (Aydin, Turkey). A total of 25 healthy adult male Wistar albino rats (Rattus rattus norvegicus) (approximately 90 days old) were used in the present study. The rats were obtained from the Department of Laboratory Animals of Aydin Adnan Menderes University (Aydin, Turkey). The animals were housed in polycarbonate rat cages under standard laboratory conditions (temperature $24+1 \mathrm{C}$, a 12-h light/dark cycle). Food (Bil-Yem, Ankara, Turkey), and water was supplied ad libitum. The duration of treatment was 16 weeks. The rats were randomly separated into two groups consisting of 10 rats in the control group and 15 rats in the experimental group. The number of animals in the experimental group was kept higher than the control group in order to ensure compliance of the data to normal distribution.

During 16 weeks, while tap water was given to the rats in the control group, water including $20 \% \mathrm{D}$ fructose solution was given to the rats in the experimental group as drinking water (Merck D (-)Fructose for Biochemistry 1.04007.0250) (De Moura et al. 2008). The fructose solution was prepared daily.

At the end of the sixteen-week experiment, animals in all groups were sacrified by cervical dislocation under ether anesthesia. After the kidneys were removed, both kidneys were weighed separately and together. 
Kidneys of animals were fixed in $10 \%$ neutral buffered formalin for 24 hours for histological examinations. Fixed tissues were embedded in paraffin, following routine procedures. The paraffin tissue blocks were cut serially at intervals of $300 \mu \mathrm{m}$ and a thickness of $6 \mu \mathrm{m}$.

\section{Histological and Histomorphological Analyzes}

Crossman's triple staining method was used for histomorphological analysis and the evaluation of histological changes in serial sections (Crossman 1937). After Crossman's triple staining, sections were examined using a light microscope. (Leica DMLB, Meyer Instruments, Inc., Houston, TX).

Corpusculum renis count was determined on three slides for each animal using triple staining method. For this purpose, corpusculum renises were counted in 15 fields in $9 \times 10^{6} \mu \mathrm{m}^{2}$ each area. Besides, corpusculum renis diameter, width of cavum glomeruli, tubulus proximalis diameter and ascending limb of Henle's loops diameter were measured. For each animal, a total of 30 corpusculum renis, tubulus proximalis and ascending limb of Henle's loop were examined and measured interactively using of image analysis program (Leica Q-Win Standard, Q-Win Plus 3.5 software, Leica Cambridge Ltd., Cambridge, UK).

\section{Histochemical Analyzes}

Periodic Acid Schiff Reagent (PAS) staining method (Culling et al. 1985) was performed to the sections for histochemical analysis and the cortex of these preparations were examined under a light microscope. Glomerular mesangial matrix density, glycogen density in tubulus proximalis epithelial cells and tubulus proximalis basement membrane thickness were determined semi-quantitatively in two sections, which were performed PAS staining method. For this purpose, a total of 20 pieces of the glomerulus and tubulus proximalis for each animal were examined with an x20 objective. Subjective scoring (0: No cell staining, 1: Low-intensity staining, 2: Moderate intensity staining, 3: Intensive staining) was performed to evaluate the staining intensity at the end of the experiment.

\section{Statistical Analysis}

A computerized statistical package SPSS (for Windows; version 22.0) was used to perform the statistical analysis. The results were presented as mean + standard deviation. A student's t-test was performed to determine the statistical difference between the obtained from control and experimental groups in terms of both individual and total weights of the kidneys, corpusculum renis diameter, width of cavum glomeruli, tubulus proximalis diameter, and ascending limb of Henle's loops diameter. Corpusculum renis count, glomerular mesangial matrix density, glycogen density in tubulus proximalis epithelial cells and tubulus proximalis basement membrane thickness were determined by MannWhitney $U$ test. The values of $\mathrm{p}<0.05, \mathrm{p}<0.01$, and $\mathrm{p}<0.001$ were considered to be statistically significant.

\section{RESULTS}

\section{Kidney weights}

Kidney weights in the control and experimental groups are given in Table 1 . When the groups were compared in terms of kidney weights, it was determined that there was no statistical difference (Table 1).

\section{Histological and histomorphological analyzes}

Kidneys of the rats in the control group have a normal histological appearance.

The corpusculum renis count, corpusculum renis diameter, width of cavum glomeruli, tubulus proximalis diameter and ascending limb of Henle's loops diameter in the control and experimental groups are given in Table 2. Corpusculum renis count determined in cross-sections using Crossman's triple staining method did not make a statistical difference between the control and experimental groups. In the experimental group, while the corpusculum renis diameter, width of cavum glomeruli and the ascending limb of Henle's loops diameter decreased $(\mathrm{p}<0.01)$, the tubulus proximalis diameter increased $(\mathrm{p}<0.01)$ (Table 2) (Figure 1, 2 and 3).

\section{Histochemical analyzes}

The glomerular mesangial matrix density, glycogen density in tubulus proximalis epithelial cells and tubulus proximalis basement membrane thickness scores in the control and experimental groups are given in Table 3. In the examination performed in terms of glomerular mesangial matrix density and glycogen density in tubulus proximalis epithelial cells in PAS stained sections, it was found that the density of the staining significantly increased in the experimental group compared to the control group $(\mathrm{p}<0.01) \quad$ (Figure 4). Also, tubulus proximalis basement membrane thickness was found to be higher in the experimental group, but no statistical significance was determined (Table 3). 

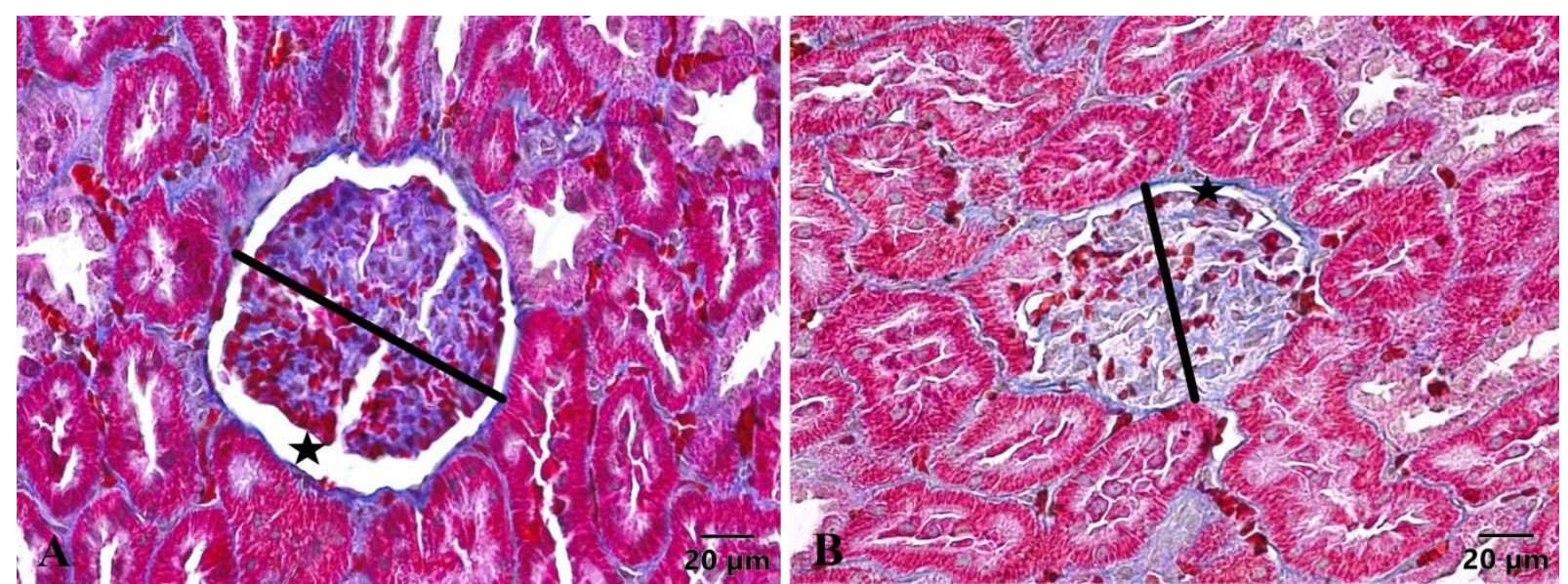

Figure 1. Corpusculum renis in the control (A) and experimental (B) groups. Corpusculum renis diameter (black lines) and width of cavum glomeruli (stars) significantly reduced in the experimental group compared to the control group. Crossman triple staining. Scale bar: $20 \mu \mathrm{m}$.
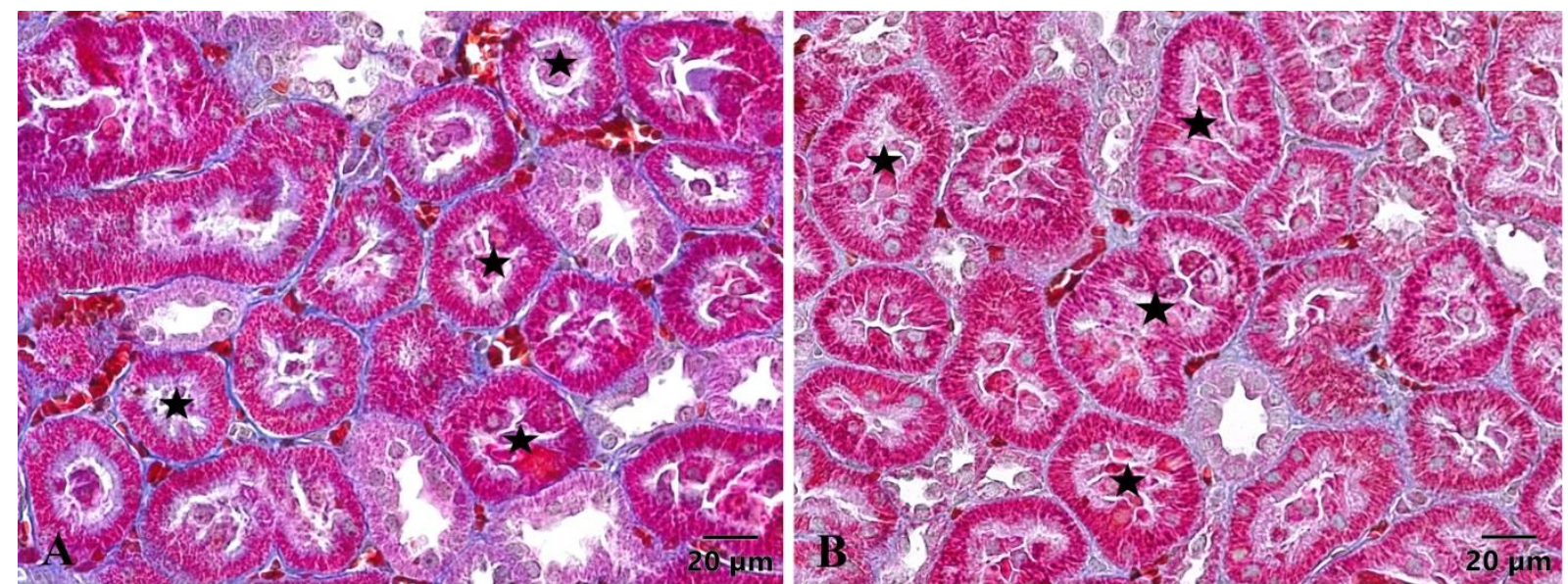

Figure 2. Tubulus proximalis (stars) in the control (A) and experimental (B) groups. Tubulus proximalis diameters were significantly higher in the experimental group than the control group. Crossman triple staining. Scale bar: $20 \mu \mathrm{m}$.

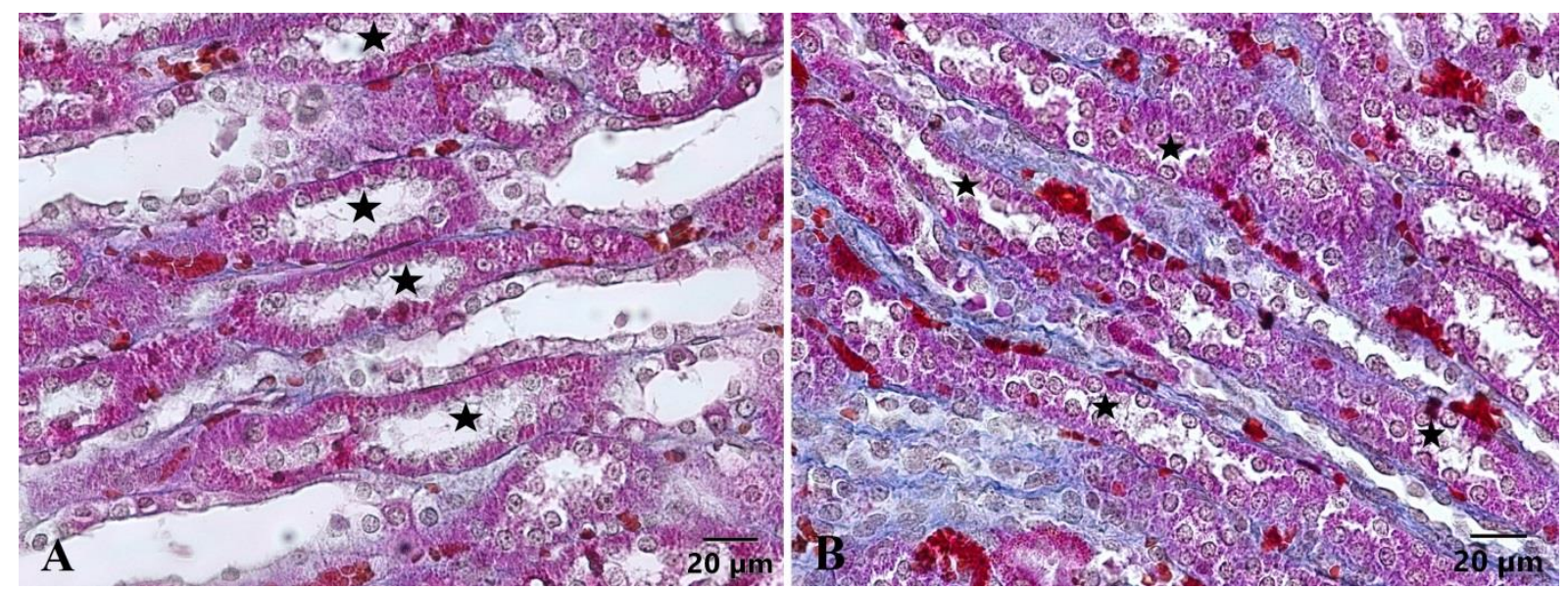

Figure 3. Ascending limb of Henle's loops in the control (A) and experimental (B) groups. Ascending limb of Henle's loops diameter (stars) significantly reduced in the experimental group compared to the control group. Crossman triple staining. Scale bar: $20 \mu \mathrm{m}$. 


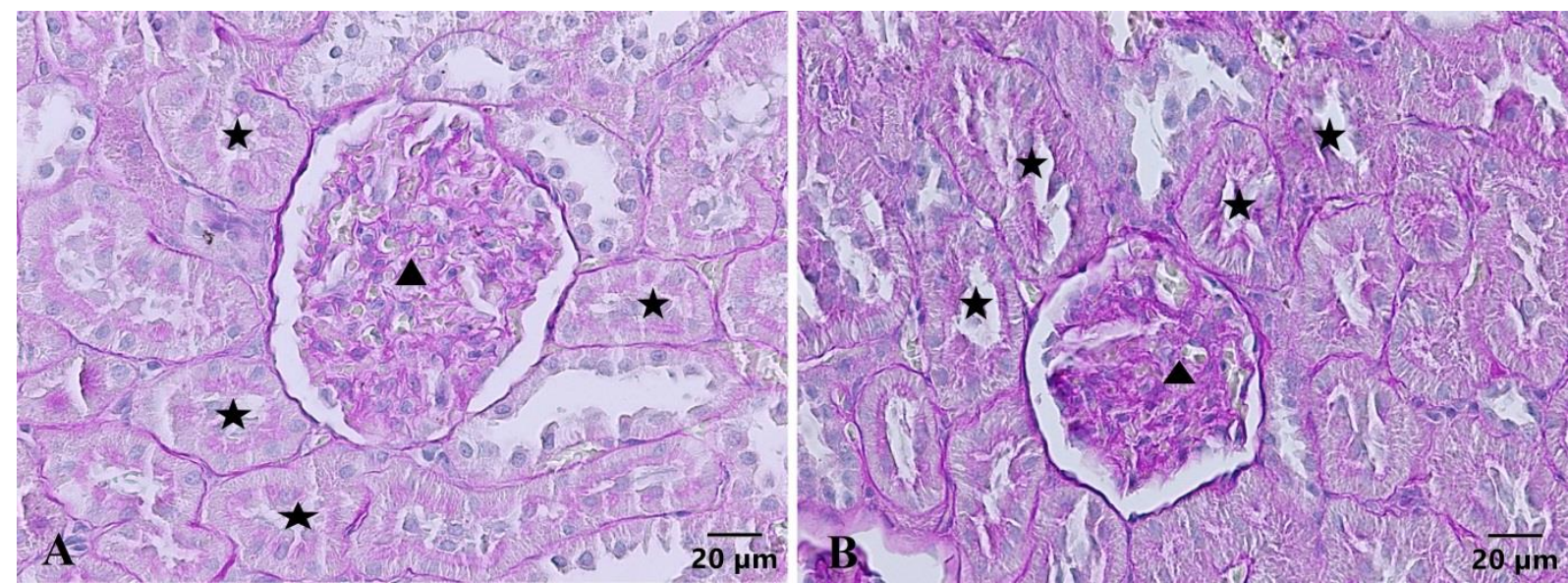

Figure 4. Corpusculum renis (triangle) and tubulus proximalis (stars) in the control (A) and experimental (B) groups. PAS-positive mesangial matrix and tubulus proximalis were significantly higher in the experimental group than the control group. PAS: Periodic acid-Shiff. PAS staining. Scale bar: $20 \mu \mathrm{m}$.

Table 1. Kidney weights in the control and experimental groups.

\begin{tabular}{lcccc}
\hline Group & $\mathbf{n}$ & $\begin{array}{c}\text { Right kidney weight } \\
(\mathbf{g})(\mathbf{x} \pm \mathbf{S x})\end{array}$ & $\begin{array}{c}\text { Left kidney weight } \\
(\mathbf{g})(\mathbf{x} \pm \mathbf{S x})\end{array}$ & $\begin{array}{c}\text { Total kidney weight } \\
(\mathbf{g})(\mathbf{x} \pm \mathbf{S x})\end{array}$ \\
\hline Control & 10 & $1.54 \pm 0.04$ & $1.44 \pm 0.03$ & $2.98 \pm 0.06$ \\
Experimental & 15 & $1.61 \pm 0.06$ & $1.43 \pm 0.04$ & $3.04 \pm 0.09$ \\
$\boldsymbol{p}$ & & $\mathrm{NS}$ & $\mathrm{NS}$ & NS \\
\hline
\end{tabular}

NS: not significant, n: no. of rats, $\mathrm{x}$ : mean, Sx: standard error of mean (SEM).

Table 2. Corpusculum renis count, corpusculum renis diameter, width of cavum glomeruli, tubulus proximalis diameter and ascending limb of Henle's loops diameter in the control and experimental groups.

\begin{tabular}{|c|c|c|c|c|c|c|}
\hline Group & $\mathrm{n}$ & $\begin{array}{l}\text { Corpusculum } \\
\text { renis } \\
\text { count }\end{array}$ & $\begin{array}{l}\text { Corpusculum } \\
\text { renis } \\
\text { diameter } \\
(\mu \mathrm{m})\end{array}$ & $\begin{array}{l}\text { Width of cavum } \\
\text { glomeruli } \\
(\mu \mathrm{m})\end{array}$ & $\begin{array}{l}\text { Tubulus } \\
\text { proximalis } \\
\text { diameter } \\
(\mu \mathrm{m})\end{array}$ & $\begin{array}{l}\text { Ascending limb of } \\
\text { Henle's loops } \\
\text { diameter ( } \mu \mathrm{m})\end{array}$ \\
\hline & & $(\mathrm{x} \pm \mathrm{Sx})$ & $(\mathrm{x} \pm \mathrm{Sx})$ & $(\mathrm{x} \pm \mathrm{Sx})$ & $(\mathrm{x} \pm \mathrm{Sx})$ & $(\mathrm{x} \pm \mathrm{Sx})$ \\
\hline Control & 10 & $6.31 \pm 0.38$ & $102.17 \pm 1.05$ & $15.83 \pm 0.25$ & $40.07 \pm 0.42$ & $30.39 \pm 0.32$ \\
\hline Experimental & 15 & $5.56 \pm 0.28$ & $95.13 \pm 0.68$ & $14.02 \pm 0.19$ & $42.24 \pm 0.36$ & $27.58 \pm 0.22$ \\
\hline$p$ & & NS & *** & $* * *$ & *** & *** \\
\hline
\end{tabular}

***: $\mathrm{p}<0.01, \mathrm{NS}$ : not significant, n: no. of rats, x: mean, Sx: standard error of mean (SEM).

Table 3. Glomerular mesangial matrix density, glycogen density in proximal tubular epithelial cells, and tubulus proximalis basement membrane thickness in the control and experimental groups.

\begin{tabular}{|c|c|c|c|c|}
\hline Group & $\mathrm{n}$ & $\begin{array}{l}\text { Glomerular } \\
\text { mesangial } \\
\text { matrix density } \\
(x \pm S x)\end{array}$ & $\begin{array}{l}\text { Glycogen density in } \\
\text { tubulus proximalis } \\
\text { epithelial cells } \\
(\mathrm{x} \pm \mathrm{Sx})\end{array}$ & $\begin{array}{c}\text { Tubulus proximalis } \\
\text { basement membrane } \\
\text { thickness } \\
(\mathrm{x} \pm \mathrm{Sx})\end{array}$ \\
\hline Control & 10 & $1.42 \pm 0.04$ & $1.38 \pm 0.03$ & $1.32 \pm 0.03$ \\
\hline $\begin{array}{l}\text { Experimental } \\
\text { p }\end{array}$ & 15 & $\begin{array}{c}2.13 \pm 0.04 \\
* * *\end{array}$ & $\begin{array}{c}1.62 \pm 0.04 \\
* * *\end{array}$ & $\begin{array}{c}1.40 \pm 0.03 \\
\mathrm{NS}\end{array}$ \\
\hline
\end{tabular}

***: $\mathrm{p}<0.01, \mathrm{NS}$ : not significant, n: no. of rats, $\mathrm{x}$ : mean, Sx: standard error of mean (SEM). 


\section{DISCUSSION}

\section{Kidney weights}

Oudot et al. (2013) and Bratoeva et al. (2017) found that feeding with high doses of fructose increases statistically kidney weight. In study by Oudor et al. (2013), this increased kidney weight due to feeding with high fructose diet was associated with kidney hypertrophy characterized by an increase in tubulus proximalis and glomerulus area. In this study, a nonsignificant difference was observed between the control and experimental group; however, a numerical increase was observed in the kidney weight of the rats in the experimental group. The reason for the absence of a significant difference is thought to be due to using a lower dose of fructose in our study than the other related studies.

\section{Histological and histomorphological analyzes}

The histological appearance of the kidney tissues in the control group was compatible with the literature (Saleh et al. 2017, El-Kafoury et al. 2019).

As a result of a study performed by adding $10 \%$ and $20 \%$ fructose to drinking water for eight weeks in rats, they found that the corpusculum renis and glomerulus area and the glomerulus diameter decreased significantly in comparison to the control group (Yanti et al. 2014, Saleh et al. 2017). In addition, Oudot et al. (2013) found that feeding with high doses of fructose increases statistically glomerulus area. In the present study, it was determined that the corpusculum renis diameter decreases in the experimental group that fructose was administered. The results were compatible with some related studies (Yanti et al. 2014, Saleh et al. 2017). The reduction in corpusculum renis diameter may be associated with interstitial fibrosis, characterized by the accumulation of matrix proteins in the kidneys due to fructose administration (Saleh et al. 2017).

Another study found that fructose administration was increased the width of cavum glomeruli, whereas width of cavum glomeruli decreased in the present study (Yanti et al. 2014). It can be thought that the reason for this decrease occurred due to the increase in glomerular mesangial matrix density.

Other studies showed that fructose administration to rats increased tubulus proximalis area in kidneys (Oudot et al. 2013, Yang et al. 2014). Consistent with literature, present study determined that the tubulus proximalis diameter increased in the experimental group. In the study of Choi et al (2011), they reported that the reason for this increase may be related to tubular cell proliferation caused by high fructose feeding of rats.

Our result showed that the diameter of the ascending limb of Henle's loops was decreased. But, in the literature review, there is no study about how fructose administration affects the diameter of the ascending limb of Henle's loops. The decrease in the diameter of ascending limb of Henle's loops may be thought to occur due to an increase in fat cell deposition and fibrous tissue formation in kidneys due to high fructose exposure (De Castro et al. 2013, Yang et al. 2014, Abdel-Kawi et al. 2016, Bratoeva et al. 2017).

\section{Histochemical analyzes}

The present study showed that increase in glomerular mesangial matrix density in rats in the experimental group was found to be compatible with the studies conducted by Kizhner and Werman (2002) and Öztürk et al (2005). Increased density in the mesangial matrix can cause mesangial sclerosis and thus kidney dysfunction (Tomooka et al. 1992). Therefore, it can be said that long-term fructose administration may negatively affect kidney function.

In the literature review, it was not found a histological study on how fructose administration affects PAS positivity in tubulus proximalis in the kidneys. In the present study, it was found that fructose administration on rats for 16 weeks increased the positivity of PAS in tubulus proxmalis. Glomerulosclerosis is characterized by mesangial cell proliferation and increased PAS positivity in the mesangial matrix. Tubular ischemia and interstitial fibrosis develop due to the progression of glomerulosclerosis. When glucosuria can not be controlled, glucose that absorbed back can be stored as glycogen in tubulus epithelium (Crawford and Cotran 1999). Therefore, it can be said that the increase in glycogen density in tubulus proximalis epithelial cells is associated with glomerulosclerosis developing due to fructose intake.

Öztürk et al. (2005) reported that the addition of $10 \%$ fructose to the drinking water of rats for eight weeks rarely increases the tubular basement membrane thickness. We found no statistically significant difference in the tubulus proximalis basement membrane thickness among the groups; however, a numerical increase was observed in the tubulus proximalis basement membrane thickness in the experimental group.

\section{CONCLUSIONS}

In the present study revealed histological changes occurring in the kidneys of the rats with metabolic syndrome, which were formed by adding $20 \%$ Dfructose to drinking water for 16 weeks. The present study showed that while the corpusculum renis diameter, width of cavum glomeruli and the ascending limb of Henle's loop diameters decreased in the experimental group. Tubulus proximalis diameters, glomerular mesangial matrix density and glycogen density in tubulus proximalis epithelial cells 
increased. In the literature review, there are no studies on how the metabolic syndrome affects the ascending limb of Henle's loop diameter and the density of glycogen staining in tubulus proximalis histologically. This is the first study that reveals this subject. These results about the effects of metabolic syndrome on kidney histochemistry and histomorphology will serve as a reference for future studies.

\section{ACKNOWLEDGEMENT}

Ethics committee report of the study was obtained from Aydin Adnan Menderes University Animal Experiments Local Ethics Committee with the number of 64583101/2016/75 dated April 18, 2016.

Conflict of Interest: The authors declare that they have no conflict of interest.

\section{REFERENCES}

Abdel-Kawi SH, Hassanin KMA, Hashem KS. The effect of high dietary fructose on the kidney of adult albino rats and the role of curcumin supplementation: A biochemical and histological study. Beni-Suef University Journal of Basic and Applied Sciences. 2016; 52-60.

Aganovic I, Dušek T. Pathophysiology of metabolic syndrome. EJIFCC. 2007; 18(1): 3-6.

Alberti KG, Zimmet PZ. Definition, diagnosis and classification of diabetes mellitus and its complications. Part 1: diagnosis and classification of diabetes mellitus provisional report of a WHO consultation. Diabet Med. 1998; 15: 539-553.

Bratoeva K, Stoyanov GS, Merdzhanova A, Radanova M. Manifestations of renal impairment in fructose-induced metabolic syndrome. Cureus. 2017; 9(11): e1826.

Bray GA, Nielsen SJ, Popkin BM. Consumption of highfructose corn syrup in beverages may play a role in the epidemic of obesity. Am J Clin Nutr. 2004; 79: 537-543.

Choi HN, Park YH, Kim JH, Kang MJ, Jeong SM, Kim HH, Kim JI. Renoprotective and antioxidant effects of Saururus chinensis Baill in rats fed a high-fructose diet. Nutr Res Pract. 2011; 5(4): 365-9.

Crawford JM, Cotran RS. The Pancreas, In: Pathologic Basis of Disease, Ed: Cotran RS, Kumar V, Collins T. WB Saunders Com, Philadelphia, USA. 1999; pp. 913-23.

Crossman GA. A modification of Mallory's connective tissue stain with a discussion of the principles involved. Anat Rec. 1937; 69(1): 33-38.

Culling CFA, Allison RT, Barr WT. Cellular pathology technique. Butterworths and Co Ltd London, 1985.

De Castro UG, dos Santos RA, Silva ME, de Lima WG, Campagnole-Santos MJ, Alzamora AC. Agedependent effect of high-fructose and high-fat diets on lipid metabolism and lipid accumulation in liver and kidney of rats. Lipids Health Dis. 2013; 12: 136.

De Moura RF, Ribeiro C, Oliveira JA, Stevanato E, Mello MAR. Metabolic syndrome signs in Wistar rats submitted to different high-fructose ingestion protocols. Br J Nutr. 2008; 101(8): 1178-1184.

El-Kafoury BMA, Ahmed MA, Hammouda GA, El Kady AH, Lasheen NN. Possible role of l-carnitine in improvement of metabolic and hepatic changes in hyperuricemic and hyperuricemic-Fructose-supplemented rats. Physiol Rep. 2019; 7(22): e14282.

Gelmez MY, Kasapoğlu P, Adaş ÇU, Tahralı İ, Bilgiç GS, Çevik A, Deniz G. Metabolik sendromda deneysel hayvan modelleri. Deneysel Tip Araştırma Enstitüsü Dergisi, 2012; 2(4): 15-21.

Işıldak M, Güven GS, Gürlek A. Metabolik sendrom ve insülin direnci. Hacettepe Tip Dergisi 2004; 35: 96-99.

Kizhner T, Werman MJ. Long-term fructose intake: biochemical consequences and altered renal histology in the male rat. Metabolism 2002; 51: 1538-1547.

Ng HY, Lee YT, Kuo WH, Huang PC, Lee WC, Lee CT. Alterations of renal epithelial glucose and uric acid transporters in fructose induced metabolic syndrome. Kidney Blood Press Res. 2018; 43(6): 1822-1831.

Oudot C, Lajoix AD, Jover B, Rugale C. Dietary sodium restriction prevents kidney damage in high fructose-fed rats. Kidney Int. 2013; 83(4): 674-683.

Öztürk F, Iraz M, Eşrefoğlu M, Kuruş M, Gül M, Otlu A. Deneysel diyabetin siçan böbreklerinde meydana getirdiği histolojik değişiklikler. İnönü Üniversitesi Tip Fakültesi Dergisi 2005; 12(1): 1-4.

Riby JE, Fusijawa T, Kretchmer N. Fructose absorption. Am J Clin Nutr. 1993; 58(5): 748-753.

Saleh R, Merghani BH, Awadin W. Effect of high fructose administration on histopathology of kidney, heart and aorta of rats. JAVAR. 2017; 4(1): 71-79.

Sanchez-Lozada LG, Tapia E, Jimenez A, Bautista $P$, Cristobal M, Nepomuceno T, Soto V, Avila-Casado C, Nakagawa T, Johnson R, Herrera-Acosta J, Franco $\mathbf{M}$. Fructose-induced metabolic syndrome is associated with glomerular hypertension and renal microvascular damage in rats. Am J Physiol Renal Physiol. 2007; 292: 423- 429.

Tomooka S, Border WA, Marshall BC, Noble NA Glomerular matrix accumulation is linked to inhibition of the plasmin protease system. Kidney Int. 1992; 42:1462 1469.

Watch W. Fructose. In: H.Pelc et al.(eds). Ullmann's Encylopedia of Industrial Chemistry, Wiley-VCH, Weinheim, Germany, 2004; pp. 474-499.

Yang M, Liu C, Jiang J, Zuo G, Lin X, Yamahara J, Wang J, Li Y. Ginger extract diminishes chronic fructose consumption-induced kidney injury through suppression of renal overexpression of proinflammatory cytokines in rats. BMC Complement Altern Med. 2014; 14: 174.

Yanti AR, Radji M, Mun'im A, Suyatna FD. Methanol Extract of Phaleria macrocarpa (Scheff.) Boerl improved renal and liver histological changes in fructose $10 \%$ induced rat. JPBR. 2014; 2(1): 79-84.

Yıldırım K. Model rats fructose-induced metabolc syndrome allopurunol the renal function on protective effect. Master thesis, Firat University, Faculty of Medicine, Elazı̆̆, 2017.

Zimmet P, Magliano D, Matsuzawa Y, Alberti G, Shaw J. The metabolic syndrome: a global public health problem and a new definition. J Atheroscler Thromb. 2005; 12: 295-300. 